\title{
Effect of dietary rape seed meal on growth performance and meat quality of growing-fattening pigs
}

\author{
A. Kargopoulos ${ }^{1}$, V. Dotas ${ }^{2}$, I. Giannenas ${ }^{3 \#}$ \& E. Christaki ${ }^{3}$ \\ ${ }^{1}$ School of Agriculture, Faculty of Agriculture, Forestry and Natural Environment, Aristotle University of Thessaloniki, \\ Thessaloniki 54124, Greece \\ ${ }^{2}$ Research Institute of Animal Science, ELGO-Dimitra, Paralimni Giannitsa, Pella 58100, Greece \\ ${ }^{3}$ Laboratory of Nutrition, School of Veterinary Medicine, Faculty of Health Sciences, Aristotle University of Thessaloniki, \\ Thessaloniki 54124, Greece
}

(Received 26 April 2018; Accepted 5 July 2018; First published online 20 November 2018)

\begin{abstract}
Copyright resides with the authors in terms of the Creative Commons Attribution 4.0 South African Licence.
See: http://creativecommons.org/licenses/by/4.0/za

Condition of use: The user may copy, distribute, transmit and adapt the work, but must recognise the authors and the South African Journal of Animal Science.
\end{abstract}

\begin{abstract}
The objective of this research was to evaluate the nutritive value of rapeseed meal (RSM) as a protein source for pigs, and the effect of graded inclusion levels of RSM as a replacement for imported soybean meal (SBM) on growth performance and carcass quality of pigs. Two trials were conducted, a digestibility trial, and a growth performance trial. In the digestibility trial, which lasted 38 days, four castrated male Large White $\times$ Landrace pigs with an initial bodyweight of $40.3 \pm 2.4 \mathrm{~kg}$ were used. Digestible energy (DE) per $\mathrm{kg}$ of RSM, digestibility energy of RSM and the apparent digestibility coefficients (\%) of RSM nutrients were assessed by the method of difference. A total of 64 (Large White $\times$ Landrace) pigs with average initial bodyweight of $11 \pm 1.3 \mathrm{~kg}$ were used in the growth performance trial. The experiment lasted 15 weeks, and was divided into three growth stages. The RSM was added to the pig diets at levels from $1 \%$ to $21 \%$. The dietary level of glucosinolates (GLS) ranged from $0.149 \mu \mathrm{mol} / \mathrm{g}$ to $3.129 \mu \mathrm{mol} / \mathrm{g}$ and RSM replaced from $3.4 \%$ to $100 \%$ of the SBM in the diets. It was proven that up to $15 \%$ of RSM of Greek origin with a GLS content of $14.9 \mu \mathrm{mol} / \mathrm{g}$ could be used in nutritionally balanced diets as an alternative to imported soybean meal for growing-finishing pigs, as it provides economic benefits and has positive effects on growth performance and carcass quality.
\end{abstract}

Keywords: Proteinaceous feedstuffs, apparent digestibility coefficients, feed cost, pork meat characteristics \#Corresponding author: igiannenas@vet.auth.gr

\section{Introduction}

Nowadays, the pig sector must seek sustainable and viable solutions to the sourcing and levels of dietary energy and nutrient inputs to remain competitive in the global market, while maintaining an acceptable level of output and animal performance. Europe is dependent on imported soybean meal (SBM) for pig diets, since the amount of this feedstuff that is used per unit of pork meat produced is $648 \mathrm{~g} / \mathrm{kg}$ (Van Gelder et al., 2008). Although SBM is an excellent vegetable protein feed, a large proportion of the imported crop is genetically modified (GM). The production of SBM also has severe environmental impacts owing to gas emissions related to changes in land use, deforestation in Latin American countries and long distances of transportation (Van Zanten et al., 2015). Moreover, the use of GM feeds elicits public concern owing to perceived health risks. In organic production in particular, the European Commission does not allow the use of GM soybeans. These sourcing concerns, along with future price uncertainty of SBM, have led to increasing debate about the use of alternative locally produced proteinaceous feeds, such as rapeseed meal (RSM), in pig diets (De Visser et al., 2014; Florou-Paneri et al., 2014). Rapeseed is grown in Europe, Canada, Australia, China, etc. for the production of protein meal for animal feeding, as well as vegetable oil for human consumption and biodiesel (McDonald et al., 2011). RSM is a by-product of the oil extraction process and contains an average of 31-37.5\% crude protein (CP), 10-12\% crude fibre (CF) and 1-2\% lipids (Okrouhlá et al., 2012). RSM has higher levels of neutral detergent fibre (NDF) than SBM (26.8\% vs 8.21\%, respectively), because of a higher content of hulls (Barthet \& Daun, 2011), and consequently has a lower digestible energy content (11.6 vs $15.2 \mathrm{MJ} / \mathrm{kg}$ ) than SBM (Yun et al., 2018). Doubts in the use of RSM in pig 
diets exist, partly because of concern about the presence of anti-nutritional factors such as glucosinolates (GLS), erucic acid (toxic), tannins and sinapine (phenols), which could significantly decrease feed consumption, and thus depress pig performance (Florou-Paneri et al., 2014). Current studies with pigs did show that RSM could replace SBM without affecting growth performance and carcass characteristics (Skoufos et al., 2016). Therefore, the aim of the present study was to extend these studies by investigating the potential of using graded dietary levels of RSM of Greek origin as a viable and sustainable alternative to imported SBM on growth performance, carcass quality and economic benefit in growing-fattening pigs.

\section{Materials and Methods}

The experimental protocols describing the animal management and care of the present studies in Laboratory of Nutrition, School of Agriculture, and commercial pig farm were in line with the animal welfare directives of the Greek Directorate General Veterinary Services.

In the digestibility trial, four castrated male Large White $\times$ Landrace pigs of an initial bodyweight of $40.3 \pm 2.4 \mathrm{~kg}$ were used and kept in individual digestibility cages during the whole trial, in the Laboratory of Nutrition, School of Agriculture, Aristotle University. Each cage was provided with a one-sided self-feeder and a nipple drinker that allowed access to feed and water throughout the experiment. The experiment lasted 38 days and was divided into three periods: one adaptation-preliminary period of 10 days, and two experimental periods of 14 days each (10 for adaptation and 4 for faecal and urine collection). During the adaptation period, all the pigs were fed a typical grower diet ad libitum based on corn and soybean meal. During the first experimental period, all pigs were fed $1500 \mathrm{~g} /$ day of the same diet, while during the second experimental period the pigs were fed $1350 \mathrm{~g}$ of the same diet and $150 \mathrm{~g}$ of RSM daily. The typical grower diet was calculated to contain $16.2 \%$ crude protein (CP) and $3175 \mathrm{kcal}$ metabolizable energy (ME)/kg (Table 1). The feed was supplied twice daily, whereas access to water was free. The pigs were housed in an environmentally controlled room. The temperature for the whole duration of the digestibility trial was set at $22.2 \pm 2.0^{\circ} \mathrm{C}$ and humidity at $55-65 \%$. RSM was obtained from a batch of seeds processed by the Greek company EL.VI. AVEE (Hellenic Biodizel, SA, Stavrohori, Kilkis) in north Greece. Faeces were collected immediately into polyethylene bags (one bag per pig) in the metabolism crates. Samples were collected daily and weights were recorded during the sample collection period. Then, $25 \%$ of faecal samples were collected in polyethylene bags and stored in a freezer for further analyses. After sorting samples by pig, they were mixed by period and pig in a large basin. Following homogenization, samples were dried at $65^{\circ} \mathrm{C}$ and then used to determine the nutrient concentrations. The determination of dry matter (DM), crude protein (CP), ether extract (EE), crude fibre (CF) and ash was according to methods 976.06, 920.39, 978.10 and 942.05, respectively, of the AOAC (1990). Neutral detergent fibre (NDF) and acid detergent fibre (ADF) were determined according to the methods of Van Soest et al. (1991). Hemicellulose was calculated as NDF minus ADF and cellulose as ADF minus ADL. Gross energy (GE) content of samples was measured by bomb calorimetry (Gallenkamp, Autobomb, automatic adiabatic bomb calorimeter). The concentrations of lysine, methionine and cystine amino acids in RSM, diets and faecal samples were calculated with a special analyser (CK-3000, Eppendorf-Biotronik; Germany). The apparent ME of the RSM was calculated according to the equation of Morgan et al. (1975): $\mathrm{ME}=\mathrm{DE} \times(0.997$ minus $0.000189 \% \mathrm{CP})$. DE per $\mathrm{kg}$ of RSM, the digestibility of RSM energy and the apparent digestibility coefficients (\%) of RSM nutrients were assessed by the method of difference (McDonald et al., 2011). The method of difference is recommended when high levels of raw materials cannot be used because of toxicity or lack of palatability (Newkirk 2009).

The growth performance experiment, which lasted 15 weeks, was carried out on a commercial pig farm in the Prefecture of Thessaloniki. A total of 64 (Large White $\times$ Landrace) pigs with an average initial bodyweight (BW) of $11 \pm 1.3 \mathrm{~kg}$ were used after weaning. Pigs were randomly assigned to four treatments with four replicate pens per treatment and four pigs per pen: 2 males and 2 females. The experiment was divided into three phases: 1st-3rd weeks, 4th-8th weeks, and 9th-15th weeks. Dietary treatments during the three phases are provided in Table 2. In the first phase, the diets consisted of control, basal diet; and RSM ${ }_{1}$, $\mathrm{RSM}_{2}$ and $\mathrm{RSM}_{3}$, containing $0 \%, 1 \%, 2 \%$ and $3 \% \mathrm{RSM}$, respectively. During the second phase the diets were control, basal diet; $\mathrm{RSM}_{6}, \mathrm{RSM}_{9}$ and $\mathrm{RSM}_{12}$, containing, $0 \%, 6 \%, 9 \%$ and $12 \% \mathrm{RSM}$, respectively, and during the third phase they consisted of control, basal diet; and $\mathrm{RSM}_{15}, \mathrm{RSM}_{18}$ and $\mathrm{RSM}_{21}$, containing $0 \%$, $15 \%, 18 \%$ and $21 \%$ RSM, respectively. The pigs were kept on the same control and RSM-based diets for the three phases of the experiment. Consequently, pigs fed the control diet during the first phase were transferred to the control diet for the next two phases. Likewise, the pigs fed the first phase of the $1 \%, 2 \%$ $3 \%$ RSM diets were transferred to $6 \%, 9 \%, 12 \%$ and $15 \%, 18 \%, 21 \%$ RSM diets of the second and third phases, respectively. The durations of the first, second and third phases of the experiment were 3,5 
Table 1 Ingredients and chemical composition of the experimental diets in the digestibility trial by method of difference (as-fed basis) [Diet in the second phase contained $10 \%$ rape seed meal compared to control diet]

\begin{tabular}{lrr}
\hline Ingredients g/kg & 1st period & 2nd period \\
\hline Maize & 700.0 & 630.0 \\
Wheat bran & 50.0 & 45.0 \\
Soybean meal (44\%) & 210.0 & 189.0 \\
Limestone & 10.0 & 9.0 \\
Dicalcium phosphate & 10.0 & 9.0 \\
Vitamins + minerals ${ }^{1}$ & 15.0 & 13.5 \\
Salt & 5.0 & 4.5 \\
Rape seed meal & - & 100.0 \\
Total & 1000 & 1000 \\
Chemical analysis (as feed basis) & & \\
Dry matter & 881.2 & 882.0 \\
Crude protein & 162.1 & 179.4 \\
Ether extract & 21.0 & 21.6 \\
Crude fibre & 34.8 & 43.3 \\
NDF** & 120.0 & 134.0 \\
ADF** & 52.6 & 63.7 \\
Lysine & 7.9 & 8.8 \\
Methionine & 2.6 & 3.1 \\
Cystine & 3.0 & 3.6 \\
Calculated nutrients* & & 3155.0 \\
ME (kcal/kg)** & 3175.0 & 6.9 \\
Calcium & 6.9 & 2.7 \\
Available phosphorus & 2.7 & \\
& & $B .7$
\end{tabular}

\footnotetext{
${ }^{1}$ Supplying per kg feed: vitamin $\mathrm{A}: 13000 \mathrm{IU}, \mathrm{D}_{3}: 5000 \mathrm{IU}, \mathrm{E}: 100 \mathrm{mg}, \mathrm{K}_{3}: 4.0 \mathrm{mg}, \mathrm{B}_{1}$ : $2.6 \mathrm{~g}, \mathrm{~B}_{2}: 8 \mathrm{mg}, \mathrm{B}_{6}: 3 \mathrm{mg}, \mathrm{B}_{12}: 0.015 \mathrm{mg}$, C: $10 \mathrm{mg}$, choline-Cl: $500 \mathrm{mg}$, niacin: $85 \mathrm{mg}$, biotin: $0.2 \mathrm{mg}$, pantothenic acid: $20 \mathrm{mg}$, folic acid: $2 \mathrm{mg}$, copper: $20 \mathrm{mg}$, iodine: $1 \mathrm{mg}$, iron: $40 \mathrm{mg}$, manganese: $120 \mathrm{mg}$, selenium: $0.3 \mathrm{mg}$, zinc: $100 \mathrm{mg}$, cobalt: $0.2 \mathrm{mg}$ *Values estimated based on NRC (2012)

** NDF: Neutral detergent fibre, ADF: acid detergent fibre, ME: metabolizable energy
}

and 7 weeks, respectively. All diets were formulated to meet or exceed the nutrient requirements recommended by NRC (2012). Each pen was equipped with a one-sided self-feeder and a nipple drinker that allowed for ad libitum access to feed and water throughout the experiment. The GLS in the RSM was calculated with the High Performance Liquid Chromatography (HPLC) method (ISO 9167-1) with a Hewlett Packard chromatograph type 1050 machine. Samples were analysed to determine DM, CP, EE, ash and CF according to the methods described by AOAC (1990). The BW of the pigs was taken at the beginning and at the end of the first, second and third phases, and feed intake and feed refusal were measured every day of the experiment to calculate average daily gain (ADG), average daily feed intake (ADFI) and feed conversion efficiency (ADG/ADFI). Before the final weighing, the pigs were subjected to four-hour fasting. At the end of the experiment, the carcasses of eight pigs (four of each sex) from each treatment were used to estimate carcass characteristics. These measurements included meat samples, from the steak of the 10th rib to chemically determine the moisture, CP, EE and ash, according to the methods described by AOAC (1990). Hot carcass weights were taken immediately after removal of blood, skin, viscera and gastrointestinal tract. The dressed weight resulted from the removal of the head, lower limbs, tail and reflex fat from the hot carcass. The thickness of the subcutaneous fat was measured at the height of the 10th side and the 6th to 7 th lumbar vertebrae. 
Table 2 Ingredients and chemical composition of experimental diets (as fed basis). During the prefattening and fattening period, graded levels of rape seed meal were introduced in the experimental diets compared to control diets

\begin{tabular}{|c|c|c|c|c|c|c|c|c|c|c|c|c|}
\hline \multirow{3}{*}{ RSM \% } & \multicolumn{12}{|c|}{ Treatments } \\
\hline & \multicolumn{4}{|c|}{ 1st phase (1st-3rd weeks) } & \multicolumn{4}{|c|}{ 2nd phase (4th-8th weeks) } & \multicolumn{4}{|c|}{ 3rd phase (9th-15th weeks) } \\
\hline & 0 & 1 & 2 & 3 & 0 & 6 & 9 & 12 & 0 & 15 & 18 & 21 \\
\hline \multicolumn{13}{|l|}{ Ingredients g/kg } \\
\hline Maize & 638.0 & 636.0 & 634.0 & 632.0 & 650.0 & 650.0 & 650.0 & 650.0 & 651.0 & 657.0 & 675.0 & 750.0 \\
\hline Barley & 120.0 & 116.0 & 115.0 & 114.0 & 164.0 & 123.5 & 101.8 & 86.8 & 201.0 & 121.0 & 96.0 & - \\
\hline Soybean meal (44\%) & 145.0 & 140.0 & 132.0 & 125.0 & 140.0 & 137.0 & 121.0 & 104.0 & 117.8 & 25.0 & 5.0 & - \\
\hline Herring & 67.0 & 67.0 & 67.0 & 67.0 & 20.0 & - & - & - & - & - & - & - \\
\hline Rapeseed oil & 4.0 & 5.0 & 6.0 & 6.0 & 4.0 & 5.0 & 10.0 & 12.0 & 8.5 & 25.0 & 25.0 & 21.0 \\
\hline $\mathrm{RSM}^{\star \star}$ & - & 10.0 & 20.0 & 30.0 & - & 60.0 & 90.0 & 120.0 & - & 150.0 & 180.0 & 210.0 \\
\hline Vitamin premix ${ }^{1}$ & 2.5 & 2.5 & 2.5 & 2.5 & 2.5 & 2.5 & 2.5 & 2.5 & 2.5 & 2.5 & 2.5 & 2.5 \\
\hline Mineral premix ${ }^{2}$ & 1.5 & 1.5 & 1.5 & 1.5 & 1.5 & 1.5 & 1.5 & 1.5 & 1.5 & 1.5 & 1.5 & 1.5 \\
\hline Salt & 5.0 & 5.0 & 5.0 & 5.0 & 5.0 & 5.0 & 5.0 & 5.0 & 5.0 & 5.0 & 5.0 & 5.0 \\
\hline Dicalcium phosphate & 10.0 & 10.0 & 10.0 & 11.0 & 8.0 & 8.0 & 10.0 & 12.0 & 4.7 & 5.0 & - & - \\
\hline Limestone & 7.0 & 7.0 & 7.0 & 6.0 & 5.0 & 7.5 & 8.2 & 6.2 & 8.0 & 8.0 & 10.0 & 10.0 \\
\hline Total & 1000.0 & 1000.0 & 1000.0 & 1000.0 & 1000.0 & 1000.0 & 1000.0 & 1000.0 & 1000.0 & 1000.0 & 1000.0 & 1000 \\
\hline \multicolumn{13}{|l|}{ Chemical analysis (as-fed basis) } \\
\hline Dry matter & 876.0 & 876.0 & 875.0 & 875.0 & 876.0 & 876.0 & 875.0 & 865.0 & 866.0 & 852.0 & 855.0 & 859.0 \\
\hline Crude protein & 180.0 & 180.0 & 180.0 & 180.0 & 150.0 & 150.0 & 150.0 & 150.0 & 130.0 & 130.0 & 130.0 & 130.0 \\
\hline Ether extract & 41.0 & 42.0 & 43.0 & 43.0 & 37.4 & 37.1 & 42.3 & 44.5 & 40.0 & 58.0 & 59.0 & 57.0 \\
\hline Crude fibre & 30.0 & 30.0 & 31.0 & 31.0 & 31.6 & 36.6 & 37.9 & 39.5 & 32.0 & 39.0 & 40.0 & 40.0 \\
\hline \multicolumn{13}{|l|}{ Calculated nutrients } \\
\hline $\mathrm{ME}(\mathrm{kcal} / \mathrm{kg})^{\star \star}$ & 3250.0 & 3250.0 & 3250.0 & 3250.0 & 3260.0 & 3260.0 & 3260.0 & 3260.0 & 3275.0 & 3275.0 & 3275.0 & 3275 \\
\hline Lysine & 10.0 & 10.0 & 10.0 & 10.0 & 7.5 & 7.5 & 7.7 & 7.6 & 6.0 & 6.2 & 6.5 & 5.6 \\
\hline Methionine + cystine & 6.2 & 6.7 & 6.9 & 6.8 & 5.4 & 5.7 & 5.8 & 6.0 & 4.7 & 5.0 & 5.2 & 5.3 \\
\hline GLS $\mu \mathrm{mol} / \mathrm{g}^{\star \star}$ & - & 0.1 & 0.3 & 0.5 & - & 0.9 & 1.3 & 1.8 & - & 2.2 & 2.7 & 3.129 \\
\hline
\end{tabular}

${ }^{1}$ Supplying per kg feed: vitamin A $13000 \mathrm{IU}, \mathrm{D}_{3} 5000 \mathrm{IU}, \mathrm{E} 100 \mathrm{mg}, \mathrm{K}_{3} 4.0 \mathrm{mg}, \mathrm{B}_{1} 2.6 \mathrm{~g}, \mathrm{~B}_{2} 8 \mathrm{mg}, \mathrm{B}_{6} 3 \mathrm{mg}, \mathrm{B}_{12} 0.015 \mathrm{mg}, \mathrm{C} 10 \mathrm{mg}, \mathrm{choline}-\mathrm{Cl} 500 \mathrm{mg}$, niacin $85 \mathrm{mg}$, biotin $0.2 \mathrm{mg}$, pantothenic acid $20 \mathrm{mg}$, folic acid $2 \mathrm{mg}$

2 Supplying per kg feed: copper (as $\mathrm{CuSO}_{4} \cdot 5 \mathrm{H}_{2} \mathrm{O}$ ), $15 \mathrm{mg}$; iron (as $\mathrm{FeSO}_{4} \bullet 7 \mathrm{H}_{2} \mathrm{O}$ ), 70 mg; zinc (as $\mathrm{ZnSO}_{4}$ ), 50 mg; manganese (as $\mathrm{MnO}_{2}$ ), 50 mg; iodine (as $\mathrm{KI}), 0.5 \mathrm{mg}$; cobalt (as $\left.\mathrm{CoSO}_{4} \cdot 7 \mathrm{H}_{2} \mathrm{O}\right), 0.3 \mathrm{mg}$; selenium $\left(\right.$ as $\left.\mathrm{Na}_{2} \mathrm{SeO}_{3} \cdot 5 \mathrm{H}_{2} \mathrm{O}\right), 0.2 \mathrm{mg}$.

* Values estimated based on NRC (2012

** ME: metabolizable energy, GLS: glucosinolates 
Economic analysis was conducted according to Choi et al. (2015) to assess the effect of feed cost on weight gain of pigs. The feed cost per weight gain was calculated based on the current price of raw materials (April 2018). In each phase, the cost index was based on feed cost per weight gain, comparing experimental diets with graded levels of RSM with the control diet.

All data of the growth performance trial were subjected to one way analysis of variance (ANOVA) in a randomized complete block design. Dunnett's control test was performed to compare means. Variability in the data was expressed as the pooled standard error and $P<0.05$ was considered statistically significant.

\section{Results}

The chemical compositions of RSM and SBM are given in Table 3. Total GSL of RSM was measured as $14.9 \mu \mathrm{mol} / \mathrm{g}$. Digestible energy of RSM and digestibility of RSM energy were $2996.6 \pm 42.3 \mathrm{kcal} / \mathrm{kg}$ and $69.1 \pm 2.03 \%$, respectively. The apparent digestibility coefficients for DM, CP, EE, CF, NDF, ADF and for the amino acids lysine, methionine and cystine were calculated as $70.4 \pm 4.45,63.4 \pm 5.23,67.3 \pm 1.94,65.5 \pm$ $2.21,52.8 \pm 6.23,51.4 \pm 3.81,64.2 \pm 0.6,66.8 \pm 1.0$ and $60.5 \pm 0.8$, respectively.

Table 3 Chemical composition of rape seed meal (RMS) and soy bean meal (SBM) (as-fed basis)

\begin{tabular}{crr}
\hline & RSM & SBM \\
\cline { 2 - 3 } & \multicolumn{2}{c}{$\mathbf{g / k g}$} \\
\hline Chemical analysis (as fed basis) & & \\
Dry matter & & 890.0 \\
Crude protein & 890.0 & 438.0 \\
Ether extract & 335.0 & 15.0 \\
NDF* & 27.3 & 133.0 \\
ADF** & 269.0 & 94.0 \\
Total GSL** $\mu \mathrm{mol} / \mathrm{g}$ & 164.0 & - \\
Calculated nutrients* & 14.9 & 28.0 \\
Lysine & & 6.0 \\
Methionine & 17.0 & 7.0 \\
Cystine & 7.0 & \\
\hline
\end{tabular}

*Values estimated based on NRC (2012)

** NDF: Neutral detergent fibre, ADF: acid detergent fibre,

GSL: glucosinolates

According to Table 4, BW and ADG did not differ significantly $(P>0.05)$ among the treatments during the growing and finishing periods. In the first three weeks of the growth performance trial (1st phase), there was no significant effects of RSM levels on ADFI and feed conversion efficiency (FCE) $(P>0.05)$, although during the 2nd phase (4th-8th weeks) FCE was significantly lower in diets with higher levels of RSM $(9-12 \%)$ than in the control diet. In the final phase (9th-15th weeks), the pigs that were fed the diets with $18 \%$ and $21 \%$ RSM showed statistically higher ADFI, resulting in a significant $(P<0.05)$ worsening in FCE, compared with the control. Throughout the experimental period (1st-15th weeks), the pigs with the highest levels of intake of RSM (2\% and 3\% in the first phase, $9 \%$ and $12 \%$ in the second phase and $18 \%$ and $21 \%$ in the third phase) showed significantly $(P<0.05)$ higher ADFI and significantly $(P<0.05)$ worse FCE compared with control. On the contrary, the lower levels of RSE (1\%, $6 \%$ and $15 \%$ during the 1 st, 2nd and 3rd phases) did not significantly affect the growth performance of the pigs compared with the control. Economic benefit was calculated by feed cost per weight gain (Table 5). Feed cost decreased slightly when dietary RSM was supplemented during the overall experiment. Furthermore, in this study carcass quality and the chemical composition of pork meat were not affected, even by total replacement of SBM with RSM up to $21 \%$ (Table 6). 
Table 4 Effect of rape seed meal supplementation on growth performance in growing-fattening pigs

\begin{tabular}{|c|c|c|c|c|c|c|}
\hline \multirow{2}{*}{ Item } & \multicolumn{4}{|c|}{ Treatments* } & \multirow{2}{*}{ SEM } & \multirow{2}{*}{$P$-value } \\
\hline & Control $^{1}$ & $\mathrm{RSM}^{\star *}{ }_{1,6,15}$ & $\mathrm{RSM}_{2,9,18}$ & $\mathrm{RSM}_{3,12,21}$ & & \\
\hline \multicolumn{7}{|l|}{$B W^{* *} \mathbf{k g}$} \\
\hline Initial & 11.0 & 11.0 & 11.0 & 11.0 & 1.21 & NS \\
\hline 1st-3rd weeks & 21.3 & 20.9 & 21.1 & 20.7 & 1.18 & NS \\
\hline 4th-8th weeks & 51.0 & 51.2 & 51.3 & 51.6 & 1.61 & NS \\
\hline 9th-15th weeks & 86.6 & 84.5 & 83.7 & 83.7 & 2.80 & NS \\
\hline 1st-3rd weeks & $0 \%$ & $1 \%$ & $2 \%$ & $3 \%$ & & \\
\hline ADG, $g$ & 490.5 & 471.4 & 481.0 & 461.9 & 18.0 & NS \\
\hline ADFI, $g$ & 930.0 & 910.0 & 950.0 & 930.0 & 30.6 & NS \\
\hline FCE & 0.5 & 0.5 & 0.5 & 0.5 & 0.021 & NS \\
\hline 4th-8th weeks & $0 \%$ & $6 \%$ & $9 \%$ & $12 \%$ & & \\
\hline ADG, $g$ & 848.6 & 865.7 & 862.9 & 882.9 & 31.0 & NS \\
\hline ADFI, $g$ & 1792.0 & 1973.0 & 2019.0 & 2101.0 & 151.2 & NS \\
\hline FCE & $0.47^{\mathrm{a}}$ & $0.44^{\mathrm{ab}}$ & $0.43^{b}$ & $0.42^{b}$ & 0.02 & * \\
\hline 9th-15th weeks & $0 \%$ & $15 \%$ & $18 \%$ & $21 \%$ & & \\
\hline ADG, $g$ & 726.5 & 679.6 & 661.2 & 655.1 & 36.0 & NS \\
\hline ADFI, $g$ & $2440^{a}$ & $2510^{\mathrm{ab}}$ & $2760^{\mathrm{ab}}$ & $2920^{b}$ & 171.1 & * \\
\hline FCE & $0.297^{\mathrm{a}}$ & $0.260^{\mathrm{ab}}$ & $0.240^{b}$ & $0.224^{b}$ & 0.02 & * \\
\hline 1st 15th weeks & $0 \%$ & $1,6,15 \%$ & $2,9,18 \%$ & $3,12,21 \%$ & & \\
\hline ADG, $g$ & 720.0 & 700.0 & 692.4 & 692.4 & 14.0 & NS \\
\hline ADFI, $g$ & $1922.0^{\mathrm{a}}$ & $2011.7^{\mathrm{ab}}$ & $2151.0^{\mathrm{bc}}$ & $2249.0^{c}$ & 55.0 & * \\
\hline FCE & $0.4^{\mathrm{a}}$ & $0.3^{\mathrm{ab}}$ & $0.3^{b}$ & $0.3^{\mathrm{b}}$ & 0.02 & * \\
\hline
\end{tabular}

*Four replications per group.

${ }^{1}$ Control: $0 \mathrm{~g} \mathrm{RSM} / \mathrm{kg}$ feed; RSM $1,6,15: 10,60$ and $150 \mathrm{~g} \mathrm{RSM} / \mathrm{kg}$ feed; RSM $2,9,18: 20,90$ and $180 \mathrm{~g} \mathrm{RSM} / \mathrm{kg}$ feed; $\mathrm{RSM}_{3,12,21}$ : 30, 120 and $210 \mathrm{~g} \mathrm{RSM} / \mathrm{kg}$ feed;

ADG: average daily gain; ADFI: average daily feed intake; FCE: feed conversion efficiency = ADG (g) / ADFI (g).

$\mathrm{a}, \mathrm{b}$, Row means with different superscripts differ significantly at $P<0.05$

NS: Not significant $(P>0.05)$

${ }^{\star *} \mathrm{RSM}$ : rape seed meal, BW: body weight

\section{Discussion}

In the current trial the authors used RSM at an inclusion level of $10 \%$. Although SBM contains more lysine than RSM, RSM has more amino acids that contain sulphur such as methionine and cystine than SBM. In contrast, the digestibility of diets containing RSM cannot be compared well with SBM (McDonnell et al., 2010), especially in terms of CF, NDF, ADF, cellulose and hemicelluloses. Nutrient digestibility is influenced by a number of factors, including the fibre from rapeseed hulls, anti-nutritional factors (tannin, sinapine, erucic acid and GLS) and dietary formulation (Patrick et al., 2010). Proteins from RSM are less digestible than those of SBM ( $72 \%$ vs $88 \%$ ), although the amino acid balance for sulphur amino acids is better than in SBM (Ho et al., 2017). The digestibility of CP and amino acids in RSM could vary, depending on the age of pigs and the quality of proteins (Stein et al., 1999). In addition, nutrient digestibility of RSM could be affected by factors such as genetic selection, environment, and the process of oil extraction (Maison, 2013). The current findings are in agreement with those of Fang et al. (2007), who reported that inclusion of RSM in pig diet in levels higher than $10 \%$ decreased digestibility of NDF fractions. 
Table 5 Influence of diets on feeding cost of growing-fattening pigs

\begin{tabular}{|c|c|c|c|c|c|c|}
\hline \multirow{2}{*}{ Item } & \multicolumn{4}{|c|}{ Treatments } & \multirow{2}{*}{ SEM } & \multirow{2}{*}{$P$-value } \\
\hline & Control $^{1}$ & $\operatorname{RSM}^{* *}{ }_{1,6,15}$ & $\operatorname{RSM}_{2,9,18}$ & $\operatorname{RSM}_{3,12,21}$ & & \\
\hline \multicolumn{7}{|l|}{ Feed cost $€ / k g$} \\
\hline 1st-3rd weeks & 0.3085 & 0.3085 & 0.3079 & 0.3072 & 0.002 & NS \\
\hline 4th-8th weeks & $0.2450^{\mathrm{a}}$ & $0.2211^{b}$ & $0.2224^{b}$ & $0.2222^{b}$ & 0.003 & * \\
\hline 9th-15th weeks & $0.2155^{\mathrm{a}}$ & $0.2128^{\mathrm{ab}}$ & $0.2084^{b}$ & $0.2060^{\mathrm{b}}$ & 0.002 & * \\
\hline 1st-15th weeks & $0.2439^{a}$ & $0.2347^{\mathrm{ab}}$ & $0.2330^{b}$ & $0.2316^{b}$ & 0.004 & * \\
\hline \multicolumn{7}{|l|}{ Feed cost per weight gain } \\
\hline 1st-3rd weeks & 0.6289 & 0.6544 & 0.6401 & 0.6651 & 0.014 & NS \\
\hline 4th-8th weeks & $0.2887^{a}$ & $0.2554^{b}$ & $0.2577^{b}$ & $0.2517^{\mathrm{b}}$ & 0.012 & * \\
\hline 9th-15th weeks & 0.2966 & 0.3131 & 0.3115 & 0.3144 & 0.013 & NS \\
\hline 1st-15th weeks & 0.3388 & 0.3353 & 0.3365 & 0.3345 & 0.008 & NS \\
\hline \multicolumn{7}{|c|}{ Feed cost per carcass gain } \\
\hline 1st-15th weeks & 0.3668 & 0.3611 & 0.3663 & 0.3664 & 0.017 & NS \\
\hline
\end{tabular}

${ }^{1}$ Control: $0 \mathrm{~g} \mathrm{RSM} / \mathrm{kg}$ feed; $\mathrm{RSM}_{1,6,15}: 10,60$ and $150 \mathrm{~g} \mathrm{RSM} / \mathrm{kg}$ feed; RSM $2,9,18: 20$, 90 and $180 \mathrm{~g} \mathrm{RSM/kg} \mathrm{feed;}$ $\mathrm{RSM}_{3,12,21}: 30,120$ and $210 \mathrm{~g} \mathrm{RSM} / \mathrm{kg}$ feed;

a, b. Row means with different superscripts differ significantly at $P<0.05$

NS: Not significant $(P>0.05)$.

${ }^{*} \mathrm{RSM}$ : rape seed meal

Table 6 Effect of different levels of rape seed meal on pig carcass weight and quality

\begin{tabular}{llllll}
\hline & \multicolumn{3}{c}{ Treatments* $^{*}$} & & \\
\cline { 2 - 4 } & Control $^{1}$ & $\mathrm{RSM}^{* *}{ }_{1,6,15}$ & $\mathrm{RSM}_{2,9,18}$ & $\mathrm{RSM}_{3,12,21}$ & $P$-value \\
\hline
\end{tabular}

\section{Carcass}

$\begin{array}{lrrrrrr}\text { Hot carcass weight, } \mathrm{kg} & 77.5 & 75.8 & 74.4 & 73.9 & 2.73 & \text { NS } \\ \text { Dressed weight, } \mathrm{kg} & 70.5 & 68.6 & 66.7 & 65.3 & 2.66 & \text { NS } \\ \text { Daily carcass gain }^{\mathrm{Y}}, \mathrm{g} & 665.0 & 650.0 & 636.0 & 632.0 & 17.2 & \text { NS } \\ \text { Subcutaneous fat, } \mathrm{cm} & 2.4 & 2.4 & 2.4 & 2.4 & 0.111 & \text { NS }\end{array}$

Proximate analysis (\%) of longissimus dorsi muscle

$\begin{array}{lcccccc}\text { Moisture } & 74.7 & 74.1 & 73.9 & 73.8 & 2.0 & \text { NS } \\ \text { Crude protein } & 22.6 & 22.4 & 22.5 & 22.4 & 0.202 & \text { NS } \\ \text { Ether extract } & 1.7 & 1.7 & 1.7 & 1.7 & 0.165 & \text { NS } \\ \text { Crude Ash } & 1.1 & 1.2 & 1.2 & 1.2 & 0.02 & \text { NS }\end{array}$

*Four replications per group

${ }^{1}$ Control: $0 \mathrm{~g} \mathrm{RSM} / \mathrm{kg}$ feed; RSM $\mathrm{RS}_{1,6,15}$ : 10, 60 and $150 \mathrm{~g} \mathrm{RSM} / \mathrm{kg}$ feed; $\mathrm{RSM}_{2,9,18}$ : 20, 90 and $180 \mathrm{~g} \mathrm{RSM/} \mathrm{kg} \mathrm{feed;}$ $\mathrm{RSM}_{3,12,21}: 30,120$ and $210 \mathrm{~g} \mathrm{RSM} / \mathrm{kg}$ feed

${ }^{Y}$ Daily carcass gain $(g)=\{($ carcass weight) - (initial bodyweight $\times 0.69)\}$ : days

NS: Not significant $(P>0.05)$

${ }^{*} \mathrm{RSM}$ : rape seed meal

In the current study, the authors used RSM at a low inclusion level of up to $3 \%$ for the age of 1-3 weeks so that pigs could be adapted to the material. In the growing and finishing phases the inclusion levels of RSM were elevated to 12 and $21 \%$, respectively, with SBM substitution up to $26 \%$ in the growing phase and $100 \%$ in the fattening phase. During the whole experiment, bodyweight was not affected by RSM graded inclusion levels in nutritionally balanced diets. ADG, ADFI and FCE in the finishing period were not affected 
by dietary supplementation of RSM of up to $15 \%$ (GLS content $2.235 \mu \mathrm{mol} / \mathrm{g}$ ). Similarly, Fang et al. (2007) recommended the use of up to $10 \%$ RSM of Chinese origin, in growing pig diets without affecting productivity negatively. The current findings are also in agreement with those of Choi et al. (2015), who used RSM of Indian origin and reported that an equal amount of GLS up to $3.07 \mu \mathrm{mol} / \mathrm{g}$ could be supplemented to growing-finishing diets without detrimental effects on growth performance of growing-finishing pigs. However, owing to its higher GLS content compared with the RSM that was used in the current experiment, the inclusion rate of Indian RSM was not higher than 9\%. On the other hand, Lee \& Hill (1983) showed that RSM decreased feed intake owing to its high content of antinutritional factors, which are associated with bitterness. It was also documented that increasing supplementation of RSM reduced ADG and ADFI linearly (King et al., 2001).

The typical tolerance level for GLS was $2.0 \mu \mathrm{mol} / \mathrm{g}$ for growing pigs, while the maximum tolerable level for weaning pigs remains to be proved (Maribo, 2010). In the current experiment the use of up to $15 \%$ RSM (GLS content $14.9 \mu \mathrm{mol} / \mathrm{g}$ ) between weaning and finishing gradually increased the GLS content in the diets of weaning pigs from 0.149 to $0.447 \mu \mathrm{mol} / \mathrm{g}$ and in the diets of fattening pigs from 0.894 to $2.2 \mu \mathrm{mol} / \mathrm{g}$, levels which did not cause adverse effects on pig performance. According to King et al. (2001), inclusion of up to $25 \%$ solvent-extracted canola meal with GLS content of $4 \mu \mathrm{mol} / \mathrm{g}$ to 9.5 in diets of weaning pigs did not have any effect on ADG or ADFI. The hydrolysis product of GLS is known to depress iodine metabolism in the thyroid gland and inhibit the synthesis of thyroid hormones $T_{3}$ and $T_{4}$ (Bell \& Belzile, 1965). When these compounds, especially thiocynates, interfere with iodine uptake, hypothyroidism and enlargement of the thyroid gland ensue. In addition, these changes affect the metabolism in all tissues, including reproductive and internal organs (Halkier \& Gershenzon, 2006). However, in the current trial, detrimental effects on the weight of the liver and other organs were not noticed. Supplemented RSM of up to $18 \%$ to $21 \%$ in fattening pig diets resulted in negative effects on ADG, ADFI and FCE, probably owing to the combined effect of high GLS (2.7 to $3.1 \mu \mathrm{mol} / \mathrm{g})$ and CF content in pig diets.

The present study supports previous evidence that RSM supplementation of up to $17 \%$ in pig diets does not affect growth performance for the duration of weaning to finishing (Skoufos et al., 2016). The addition of RSM to pig diets did not cause statistically significant effects on carcass yields or among dietary treatments on performing proximate analyses of the pork meat (longissimus dorsi). Growth performances of finishing pigs were influenced by feed nutrients, although the chemical composition of their carcasses was not. The ability of pigs to digest CF in the diet is affected by their age and bodyweight (Le Goff et al., 2003). However, Jorgensen et al. (1996) suggested that pig intake diets with higher levels of CF show an abnormally high ADG compared with pig intakes diets with normal levels of CF. This assumption was based on the premise that a diet with a high level of CF causes a significant increase in the weight and size of the digestive tract, mainly as a result of the high water retention capacity of CF (Qin et al., 2002) Therefore, a more accurate method of determining the real ADG for pig intake diets with different CF contents would probably be to determine the average daily carcass gain, which was determined in this study, with the assumption that the carcass ratio in young piglets at the start of the experiment was $69 \%$. The factor of 0.69 was used to estimate carcass weight from initial live weight. This value was previously determined with five male and five female piglets slaughtered at $20 \mathrm{~kg}$ live weight (Batterham et al., 1986).

The $3.8 \%$ and $5.6 \%$ decrease in dressed weight for the pigs fed the highest levels of RSM was probably because of the increase in the weight of visceral organs and intestinal tract and increased digestive tract digesta (Jorgensen et al., 1996; Qin et al, 2002). Moreover, RSM inclusion up to 21\% fully replaced SBM had no significant effect on meat quality since neither carcass characteristics nor chemical composition were influenced.

The results of the present study are in agreement with those of McDonnell et al. (2010) and Skoufos et al. (2016), which did not observe significant effects of the RSM level of the diet on the depth of subcutaneous fat and lean meat percentage. The lack of negative effects of dietary RSM on pig performance, even at high inclusion levels and total replacement of SBM, support the hypothesis that the gradual increase of the RSM level in pig diets is tolerated owing to the graded adaptation of the pig organism to the undesirable effects of GLS, eliminating a significant part of their adverse effects.

The cost per $\mathrm{kg}$ of feed was lower in the groups that received the RSM compared with the SBM control diet. The costs of feed intake per kg of weight gain and feed cost per carcass gain were not different among the experimental groups. Inclusion of RSM did not negatively affect the quality of the meat or its economic production traits. Maintenance of production cost of pork meat by using local feedstuffs instead of imported ones may provide extra benefits to the producers as it is more eco-friendly and more desirable by consumers with high awareness on environmental concerns and genetically modified feedstuffs. 


\section{Conclusion}

From the present study it is evident that RSM of Greek origin could be considered a viable, ecofriendly and cost-effective alternative protein source to imported SBM in nutritionally balanced diets of growing and fattening pigs up to $3 \%$ (GLS: $0.447 \mu \mathrm{mol} / \mathrm{g}$ ) during the first phase of fattening (1-3 weeks), $6 \%$ (GLS:0.894 $\mu \mathrm{mol} / \mathrm{g}$ ) during the second phase (4-8 weeks) and $15 \%$ (GLS: $2.235 \mu \mathrm{mol} / \mathrm{g}$ ) during the third phase (9-15 weeks), without adverse effects on their growth performance. Moreover, RSM used at any level up to $21 \%$ (GLS: $3.129 \mu \mathrm{mol} / \mathrm{g}$ ) had no influence on the traits of carcass quality of the pigs, including carcass weight and chemical composition.

\section{Authors' Contributions}

Conceptualization: AK, EC, Methodology: AK, VD, Writing original draft: AK, IG, Writing, review \& editing: all authors read and approved the final manuscript.

\section{Conflict of Interest Declaration}

The authors declare that there was no conflict of interest.

\section{References}

Association of Official Analytical Chemists (AOAC) 1990. Official methods of analysis. 15th ed. AOAC, Arlington, VA, USA.

Barthet, V.J. \& Daun, J.K., 2011. Seed morphology, composition, and quality. In J.K. Daun, N.A.M. Eskin, D. Hickling, (eds). Canola: Chemistry, production, processing and utilization. AOCS Press, Urbana, IL.

Batterham, E.S., Andersen, L.M., Lowe, R.F. \& Darnell, R.E., 1986. Nutritional value of lupin (Lupinus albus)-seed meal for growing pigs: Availability of lysine, effect of autoclaving and net energy content. Br. J. Nutr. 56, 645-659.

Bell, J.M. \& Belzile, R., 1965. Rapeseed meal for livestock and poultry: A review. Canadian Department of Agriculture, Ottawa, Canada.

Choi, H.B., Jeong, J.H., Kim, D.H., Lee, Y., Kwon, H. \& Kim, Y.Y., 2015. Influence of rapeseed meal on growth performance, blood profiles, nutrient digestibility and economic benefit of growing-finishing pigs. Asian-Austral. J. Anim. Sci. 28,1345-1353.

De Visser, C.L.M., Schreuder, R. \& Stoddard, F., 2014. The EU's dependency on soya bean import for the animal feed industry and potential for EU produced alternatives. OCL 2014, 21(4) D407. Available: www.ocl-journal.org.

Fang, Z.F., Peng, J., Tang, T.J., Liu, Z.L., Dai, J.J. \& Jin, L.Z., 2007. Xylanase supplementation improved digestibility and performance of growing pigs fed Chinese double-low rapeseed meal inclusion diets: In vitro and In vivo studies. Asian-Austral. J. Anim. Sc. 20, 1721-1728. Doi: https://doi.org/10.5713/ajas.2007.1721

Florou-Paneri, P., Christaki, E., Giannenas, I., Bonos, E., Skoufos, I., Tsinas, A., Tzora, A. \& Peng, J., 2014. Alternative protein sources to soybean meal in pig diets. J. Food Agric. Environ. 12, 655-660.

Halkier, B.A. \& Gershenzon, J., 2006. Biology and biochemistry of glucosinolates. Ann. Rev. Plant Biol. 57, 303-333.

Ho, D.S., Kim, B.O., Fang, L.H., You, D.H., Hong, J. \& Kim, Y.Y., 2017. Various levels of rapeseed meal in weaning pig diets from weaning to finishing periods. Asian-Austral. J. Anim. Sci. 30, 1292-1302.

Jørgensen, H., Jensen, S.K. \& Eggum, B.O., 1996. The influence of rapeseed oil on digestibility, energy metabolism and tissue fatty acid composition in pigs. Acta Agric. Scand. Sect. A. Anim. Sci. 46, 65-75.

King, R.H., Eason, P.E., Kerton, D.K. \& Dunshea, F.R., 2001. Evaluation of solvent-extracted canola meal for growing pigs and lactating sows. Austral. J. Agric. Res. 52, 33-41.

Lee, P.A. \& Hill, R., 1983. Voluntary food intake of growing pigs given diets containing rapeseed meal, from different types and varieties of rape, as the only protein supplement. Br. J. Nutr. 50, 661-671.

Le Goff, G., Noblet, J. \& Cherbut, C. 2003. Intrinsic ability of the faecal microbial flora to ferment dietary fibre at different growth stages of pigs. Livest. Prod. Sci. 81, 75-87.

Maison, T., 2013. Evaluation of the nutritional value of canola meal, 00-rapeseed meal, and 00-rapeseed expellers fed to pigs. Thesis. Department of Animal Science, University of Illinois, Urbana-Champaign.

Maribo, H., 2010. Weaner fed with 15\% rapeseed cake or rapeseed meal. Pig Research Centre. Trial no 890.

McDonald, P., Edwards, R.A., Greenhalgh, J.F.D., Morgan, C.A., Sinclair, L.A. \& Wilkinson, R.G., 2011. Animal Nutrition. 7th edition. Prentice Hall, Pearson Publishing, Essex, UK.

McDonnell, P., O'Shea, C., Figat, S. \& O'Doherty, J.V., 2010. Influence of incrementally substituting dietary soya bean meal for rapeseed meal on nutrient digestibility, nitrogen excretion, growth performance and ammonia emission from growing-finishing pigs. Arch. Anim. Nutr. 65, 412-424.

Morgan, C., Cole, A. \& Lewis, D., 1975. Energy values in pig nutrition. II. The prediction of energy values from a dietary chemical analysis. J. Agri. Sci. 84, 19-27.

Newkirk, R., 2009. Canola meal. Feed industries guide. 4th edition. Canadian International Grains Institute, Winnipeg, Manitoba.

NRC., 2012. Nutrient Requirements of Swine. 11th revised edition. National Academy Press, Washington, DC., USA.

Okrouhlá, M., Stupka, R., Čítek, J., Šprysl, M., Brzobohatý, L. \& Kluzáková, E., 2012. The effect of addition of rapeseed meal on the quality of pork meat and fat. Research in Pig Breeding 6, 52-54.

Patrick, M., O'Shea, C., Figat, S. \& O'Doherty, J.V., 2010. Influence of incrementally substituting dietary soya bean meal for rapeseed meal on nutrient digestibility, nitrogen excretion, growth performance and ammonia emissions from growing-finishing pigs. Arch. Anim. Nutr. 64, 412-424. 
Qin, G.X., Xu, L.M., Jiang, H.L., Van der Poel, A.F.B., Bosch, M.W. \& Vestegen, M.W.A., 2002. The effects of Chinese and Argentine soyabeans on nutrient digestibility and organ morphology in Landrace and Chinese Min pigs. Asian-Austral. J. Anim. Sci. 15:555-564.

Skoufos, I., Tzora, A., Giannenas, I., Bonos, E., Papagiannis, N., Tsinas, A., Christaki, E. \& Florou-Paneri, P., 2016. Dietary inclusion of rapeseed meal as soybean meal substitute on growth performance, gut microbiota, Oxidative stability and fatty acid profile in growing-fattening pigs. Asian J. Anim. Vet. Adv. 11, 89-97.

Stein, H.H., Aref, S. \& Easter, R.A., 1999. Comparative protein and amino acid digestibilities in growing pigs and sows. J. Anim. Sci. 77, 1169-1179.

Van Gelder, J.W., Kammeraat, K. \& Kroes, H., 2008. Soy consumption for feed and fuel in the European Union. Profundo Economic Research. Profundo, Castricum, Netherlands. Available at: Available at: https://milieudefensie.nl/publicaties/rapporten/soy-consumption-for-feed-and-fuel-in-the-european-union. Accessed 19 April 2014.

Van Soest, P.J., Robertson, J.B. \& Lewis, B.A., 1991. Methods for dietary fibre, neutral detergent fibre and non-starch polysaccharides in relation to animal nutrition. J. Dairy Sci. 74, 3583-3597.

Van Zanten, H.H.E., Bikker, P., Mollenhorst, H., Meerburg, B.G. \& de Boer, I.J.M., 2015. Environmental impact of replacing soybean meal with rapeseed meal in diets of finishing pigs. Animal 9, 1866-1874.

Yun, H.M., Lei, X.J., Lee, S.I. \& Kim, I.H., 2018. Rapeseed meal and canola meal can partially replace soybean meal as a protein source in finishing pigs. J. Appl. Anim. Res. 46, 195-199. 